\title{
Attenuation of hedgehog/GLI signaling by NT1721 extends survival in pancreatic cancer
}

\author{
Claudia M. Kowolik ${ }^{1 \dagger}$, Min Lin ${ }^{1 \dagger}$, Jun Xie ${ }^{1}$, Larry E. Overman² and David A. Horne ${ }^{1 *}$
}

\begin{abstract}
Background: Pancreatic cancer is one of the most lethal malignancies due to frequent late diagnosis, aggressive tumor growth and metastasis formation. Continuously raising incidence rates of pancreatic cancer and a lack of significant improvement in survival rates over the past 30 years highlight the need for new therapeutic agents. Thus, new therapeutic agents and strategies are urgently needed to improve the outcome for patients with pancreatic cancer. Here, we evaluated the anti-tumor activity of a new natural product-based epidithiodiketopiperazine, NT1721, against pancreatic cancer.
\end{abstract}

Methods: We characterized the anticancer efficacy of NT1721 in multiple pancreatic cancer cell lines in vitro and in two orthotopic models. We also compared the effects of NT1721 to clinically used hedgehog inhibitors and the standard-of-care drug, gemcitabine. The effect of NT1721 on hedgehog/GLI signaling was assessed by determining the expression of GLI and GLI target genes both in vitro and in vivo.

Results: NT1721 displayed IC 50 values in the submicromolar range in multiple pancreatic cancer cell lines, while largely sparing normal pancreatic epithelial cells. NT1721 attenuated hedgehog/GLI signaling through downregulation of GLI1/2 transcription factors and their downstream target genes, which reduced cell proliferation and invasion in vitro and significantly decreased tumor growth and liver metastasis in two preclinical orthotopic mouse models of pancreatic cancer. Importantly, treatment with NT1721 significantly improved survival times of mice with pancreatic cancer compared to the standard-of-care drug, gemcitabine.

Conclusions: Favorable therapeutics properties, i.e. 10-fold lower $I C_{50}$ values than clinically used hedgehog inhibitors (vismodegib, erismodegib), a $90 \%$ reduction in liver metastasis and significantly better survival times compared to the standard-of-care drug, gemcitabine, provide a rational for testing NT1721 in the clinic either as a single agent or possibly in combination with gemcitabine or other therapeutic agents in PDAC patients overexpressing GLI1/2. This could potentially result in promising new treatment options for patients suffering from this devastating disease.

Keywords: Pancreatic cancer, Epidithiodiketopiperazine, ETP, NT1721, GLI, Hedgehog signaling, Metastasis, Orthotopic model

\footnotetext{
* Correspondence: dhorne@coh.org

${ }^{\dagger}$ Claudia M. Kowolik and Min Lin contributed equally to this work.

${ }^{1}$ Department of Molecular Medicine, City of Hope National Medical Center,

1500 E. Duarte Road, Duarte, CA 91010, USA

Full list of author information is available at the end of the article
}

(c) The Author(s). 2019 Open Access This article is distributed under the terms of the Creative Commons Attribution 4.0 International License (http://creativecommons.org/licenses/by/4.0/), which permits unrestricted use, distribution, and reproduction in any medium, provided you give appropriate credit to the original author(s) and the source, provide a link to the Creative Commons license, and indicate if changes were made. The Creative Commons Public Domain Dedication waiver (http://creativecommons.org/publicdomain/zero/1.0/) applies to the data made available in this article, unless otherwise stated. 


\section{Background}

Pancreatic cancer is one of the most lethal cancers and the 4th leading cause of cancer-related deaths in the United States. Incidence rates have been on the raise over the past several years: According to the American Cancer Society an estimated 56,770 new cases will be diagnosed and 45,750 will die from the disease in 2019 [1]. Due to the lack of early symptoms and detection methods, most patients are diagnosed with pancreatic ductal adenocarcinoma (PDAC) at an advanced stage when the tumor has metastasized and is not resectable [2]. Gemcitabine became the standard-of-care drug for PDAC two decades ago, improving median survival compared to treatment with 5-fluorouracil (5.6 vs. 4.4 months) [3]. In recent clinical trials combinations of gemcitabine with other drugs resulted in relatively modest improvements of the median survival times [4]. A clinical trial with FOLFIRINOX vs. gemcitabine showed significantly improved median survival rates (11.1 vs. 6.8 months) in metastatic PDAC, but this regimen is associated with much higher toxicity rates that can only be tolerated by very few patients [5]. Despite these advances, overall prognosis and survival rates have not substantially improved over the past three decades, remaining at an overall 5 -year survival rate of $1-5 \%$ for patients with metastatic PDAC [1,2]. Major causes for treatment failure are aggressive growth, early metastasis, the development of gemcitabine resistance and enrichment for cancer stem cells (CSCs) that survive chemotherapy and promote tumor recurrence $[2,6,7]$. Hence, there is an urgent need to develop new drugs that can overcome the drug resistance and improve the outcome for patients with pancreatic cancer.

The sonic hedgehog $(\mathrm{HH})$ pathway is a major regulator of cell proliferation, differentiation and polarity that is frequently aberrantly activated in a variety of cancers $[4,8,9]$. Canonical HH signaling is initiated through binding of sonic hedgehog $(\mathrm{SHH})$ to its receptor PTCH1, which ultimately results in the activation of the zinc finger transcription factors GLI1/2 and the expression of GLI target genes [8]. GLIdependent transcription can also occur in the absence of SHH since GLI transcription factors can be positively regulated by PI3K-AKT, KRAS or TGF $\beta 1$ [10-12]. GLI target genes (e.g. GLI1, PTCH1, BCL2, BMI1, DNMT1, CCNE1, $A B C G 2)$ are involved in a wide variety of cellular processes such as HH pathway feedback, proliferation, apoptosis and stem cell self-renewal [8, 13-16]. Aberrant activation of HH/GLI signaling has been implicated in increased proliferation, CSC signaling, epithelial-to-mesenchymal transition (EMT) and thus increased metastasis in several types of cancer including PDAC $[16,17]$. Moreover, increased HH signaling may also contribute to gemcitabine resistance in PDAC. Gemcitabine-resistant PDAC cells display increased expression levels of members of the $\mathrm{HH}$ pathway, CSC and
EMT markers compared to the gemcitabine-sensitive parental cells [7, 17]. Various studies have shown that blocking $\mathrm{HH}$ signaling with a SMO inhibitor (cyclopamine) decreases the $\mathrm{IC}_{50}$ values for gemcitabine, downregulates CSC markers and inhibits invasion and metastases in PDAC cells [17, 18]. Thus, targeting the HH/GLI pathway has emerged as promising strategy for the treatment of pancreatic cancer.

Epidithiodiketopiperazines (ETPs) are a broad class of fungal metabolites with potent antitumor activity in multiple solid and non-solid tumors. Here, we show for the first time that the biological activity of an ETP, NT1721, is associated with attenuated HH/GLI signaling. We demonstrate that NT1721 reduced the expression of GLI and GLI target genes in pancreatic cancer cell lines and two orthotopic mouse models. NT1721mediated downregulation of genes associated with EMT resulted in significantly decreased metastases in vivo. Importantly, NT1721 also significantly increased survival times in an orthotopic model of pancreatic cancer compared to the control and gemcitabine-treated groups, highlighting its potential as new agent for the treatment of pancreatic cancer.

\section{Material and methods Reagents}

NT1721 was synthesized as previously described [19]. Erismodegib and vismodegib were purchased from ApexBio (Houston, TX, USA).

\section{Cell culture}

Panc1, Capan1, SU.86.86 and BxPC3 cells were obtained from ATCC (Manassas, VA, USA), authenticated by STR-profiling at the source and passaged for less than 6 months after receipt or resuscitation. The cells were cultured in DMEM (Panc1, Capan1) or RPMI (SU.86.86 and BxPC3) supplemented with 10\% FBS (Atlas Biologicals, Fort Collins, CO, USA). Luciferase-expressing (luc ${ }^{+}$) Panc1 and Capan1 cells were generated as previously described [20]. Immortalized, non-tumorigenic human pancreatic duct epithelial cells (HPDEC) were obtained from AddexBio (San Diego, CA, USA). Normal primary human pancreatic epithelial cells were purchased from Cell Systems (Kirkland, WA, USA) and cultured in Complete Serum-Free Medium with RocketFuel ${ }^{\mathrm{mix}}$ (Cell Systems).

\section{Determination of $\mathrm{IC}_{50}$ values}

The cell viability and $\mathrm{IC}_{50}$ values were determined as previously described [20] using the MTS assay (CellTiter $96^{\circ}$ AQueous One Solution, Promega, Madison, WI, USA); briefly, 7500 cells/well were seeded in 96-well plates, cultured overnight and then treated with various concentrations of NT1721 for $48 \mathrm{~h}$. Data from the MTS 
assay were expressed as percent of viable cells compared to the vehicle control $(0.3 \%$ DMSO).

\section{Proliferation assay}

Cells were stained with CSFE ((5)6)-Carboxyfluorescein $\mathrm{N}$-hydroxysuccinimidylester, CellTrace ${ }^{\mathrm{rm}}$, ThermoFisher, Waltham, MA, USA) according to the manufacturer's instructions, seeded at a concentration of 100,000 cells/ well in 12-well plates and allowed to attach overnight. The cells were treated with NT1721 or DMSO the next day, harvested after 24,48 or $72 \mathrm{~h}$, stained with $0.2 \mu \mathrm{g} /$ $\mathrm{ml}$ DAPI and subjected to FACS analysis. Fluorescence data were collected on a CyAN flow cytometer (Beckman Coulter, Brea, CA, USA) and analyzed with Flowjo software (TreeStar, Ashland, OR, USA).

\section{Cell cycle analysis}

Cells were treated with NT1721 and harvested after $24 \mathrm{~h}$, stained with propidium iodide (PI) (ThermoFisher) as previously described and subjected to FACS analysis [20].

\section{QPCR}

Total RNA was isolated using the Direct-zol kit (Zymo Research, Irvine, CA, USA) and reverse transcribed using the Tetro cDNA synthesis kit (Bioline, Taunton, MA, USA).

The following qPCR primers were used:

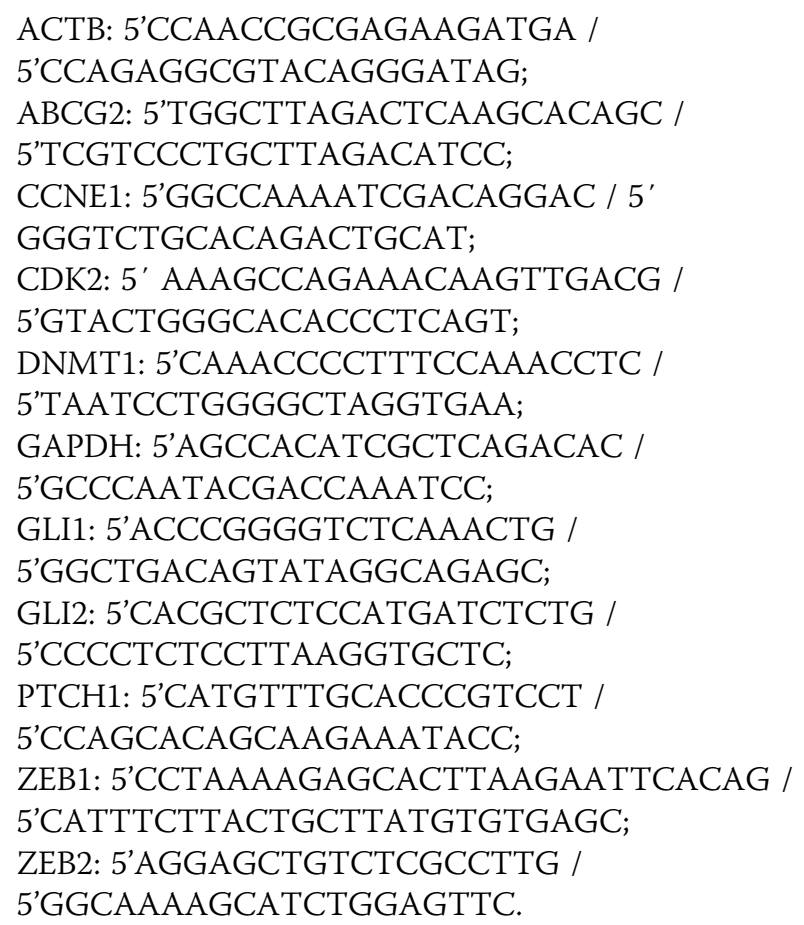

Quantitative PCR was performed using a CFX96 Touch Real-Time PCR detection system (Bio-Rad). Relative expression levels were calculated using the
$2^{-\Delta \Delta C t}$ method and GAPDH or ACTB as reference gene.

\section{Western blots}

SDS-PAGE and Western blots were carried out as previously described [20]. Briefly, cells were lyzed using RIPA buffer (Cell signaling, Danvers, MA, USA) supplemented with Halt Protease inhibitor cocktail (ThermoFisher Scientific). The protein concentration was quantified using the Pierce BCA Protein Assay Kit (ThermoFisher Scientific). Equal amounts of protein were loaded on precast gels (Bio-Rad, Hercules, CA, USA), transferred to PVDF membranes (Bio-Rad) using the Trans-Blot Turbo Transfer System (Bio-Rad). Membranes were blocked for $1 \mathrm{~h}$ at RT in blocking buffer (5\% w/v nonfat dry milk, $0.1 \%$ Tween-20 in TBS), incubated with primary antibodies overnight at $4{ }^{\circ} \mathrm{C}$. Primary antibodies were purchased from Cell signaling (CDH2 (\#13116), $\beta$-actin (\#4970), BIM (\#2933), BMI1 (\#69640, DNMT1 (\#5031), GAPDH (\#5174), H3 (\#4499), p21 (\#2947), ABCG2 (\#42078), BCL2 (\#4223), CDK2 (\#2546), MMP2 (\#13132)), from Santa Cruz Biotchnology (GLI2 (sc-271,786), GLI1 (sc-20,687), ZEB2 (sc-271,984)), from Millipore (Burlington, MA, USA) (PTCH1 (06-1102)), from ThermoFisher (myc tag (\# MA1-21316)) and from Genetex (Irvine, CA, USA) (ZEB1 (GTX55847)). The membranes were washed three times with TBS and then incubated $1 \mathrm{~h}$ at RT with the appropriate secondary antibodies. Bands were visualized using X-ray film or the ChemiDoc Imaging System (Bio$\mathrm{Rad}$ ) and analyzed with ImageJ or with Image Lab Software (Bio-Rad).

\section{GLI reporter assay}

To establish a GLI reporter cell line, Capan1 cells were transduced with a lentiviral vector (pGreenFire1 tmGLI-EF1-Neo, SBI System Biosciences, Palo Alto, CA, USA) that expresses firefly luciferase under the control of four GLI response elements. Transduced cells were selected with $600 \mu \mathrm{g} / \mathrm{ml} \mathrm{G418}$. Capan1 GLI reporter cells were seeded in 96-well plates (12,000 cells/well), allowed to attach over night and then treated with NT1721, erismodegib or vismodegib. The medium was removed after $36 \mathrm{~h}$ and D-luciferin $(300 \mu \mathrm{g} / \mathrm{ml})$ was added. The luminescence was measured after $5 \mathrm{~min}$ of incubation at $37^{\circ} \mathrm{C}$. The luminescence values were normalized to the protein concentration (Pierce BCA Protein Assay Kit) and then to the DMSO control.

\section{Invasion assay}

To quantify the invasion of PDAC cell lines through the basement membrane we performed the CytoSelect ${ }^{\text {Tw }}$ 96Well Cell Invasion Assay (Cell Biolabs, San Diego, CA, USA) according to the manufacturer's instructions. 


\section{GLI2 overexpression}

Plasmid pCS2-MT GLI2 delta N (\#17649) expressing GLI $2 \Delta \mathrm{N}$, which displays strong transcriptional activity [21], was obtained from Addgene (Watertown, MA, USA). Panc1 and Capan1 cells were transfected with pCS2-MT GLI2 delta N or a GFP-expressing control plasmid using jetPrime transfection reagent (Polyplus New York, NY, USA) according to the manufacturer's instructions. The cells were trypsinized after $16 \mathrm{~h}$, seeded into multiple wells, allowed to attach $(8 \mathrm{~h})$ and treated with NT1721 for $48 \mathrm{~h}$.

\section{In vivo studies}

Mouse care and experimental procedures were performed under pathogen-free conditions in accordance with approved protocols from the institutional animal care and use committee of City of Hope National Medical Center. For the orthotopic model, $5 \times 10^{5}$ luciferaseexpressing Panc1 or Capan1 cells were injected into the pancreas of 6-to 8-week old male NSG mice (Jackson Laboratory, Bar Harbor, ME, USA). To determine the tumor burden, we injected the mice (I.P.) with $3 \mathrm{mg}$ DLuciferin (Promega) 12 days after tumor injection and imaged them in an IVIS 100 (Caliper Life Sciences). A standard region of interest (ROI), which included the entire mouse, was used to determine the total body bioluminescence. Data were expressed as photons $/ \mathrm{s} / \mathrm{mm}^{2}$. The mice were then distributed into groups bearing equal tumor burdens and treated with NT1721 $(30 \mathrm{mg} /$ $\mathrm{kg}$ on 3 consecutive days per week by gavage) or gemcitabine $(100 \mathrm{mg} / \mathrm{kg}$, twice per week on non-consecutive days by I.P. injection). The control groups for NT1721 and gemcitabine received the vehicle control (5\% DMSO / 30\% solutol (Sigma, St. Louis, MO, USA)) and PBS, respectively.

\section{Microscopy}

H\&E (Hematoxylin \& Eosin) stained tissue slides were prepared from formalin-fixed mouse livers using standard methods. Pictures of these tissue slides were taken using a Zeiss Observer Z1 Widefield Microscope with a 506 Axioam Color Camera (Tiling option in Zen Blue software, $10 \%$ overlap) and analyzed with Image Pro Premier software (Media Cybernetics) to determine the number of tumor foci $/ \mu \mathrm{m}^{2}$.

\section{Statistical analysis}

The mean \pm standard deviation (SD) was calculated for each treatment group. Unless noted otherwise, the 2tailed t-test with Welch's correction was used to determine statistical significance between two treatment groups. The log-rank test was used to evaluate the statistical significance in survival curves. $p$ values $<0.05$ were considered to be significant.

\section{Results}

NT1721 displayed $\mathrm{IC}_{50}$ values in the nanomolar range in multiple PDAC cell lines

To evaluate the potency of NT1721 against PDAC we treated four pancreatic cancer cell lines (derived from either primary tumors (Panc1, BxPC3) or from liver metastases (Capan-1, SU.86.86)) with NT1721 and determined their viability and the $\mathrm{IC}_{50}$ values after $48 \mathrm{~h}$. As shown in Fig. 1a, the $\mathrm{IC}_{50}$ values were all $<1 \mu \mathrm{M}$, ranging from $\sim 150$ to 800 $\mathrm{nM}$, depending on the cell line. To assess the effect of NT1721 on normal cells we also treated normal primary as well as immortalized, non-tumorigenic pancreatic duct epithelial cells (HPDEC) with NT1721. As shown in Fig. 1b, NT1721 decreased the viability of the PDAC cell lines while $\geq 75 \%$ of the normal primary and HPDEC cells remained viable at a concentration of $1 \mu \mathrm{M}$ NT1721, suggesting that NT1721 may preferentially decrease the viability of pancreatic tumor cells. We used invasive Panc1 and Capan1 cells, expressing mutated KRAS, which is prevalent in the majority of PDAC patients, to investigate the effect of NT1721 on PDAC in vitro and in vivo.

NT1721 decreased proliferation and cell cycle progression We investigated the effect of NT1721 on the proliferation rate by staining Panc1 and Capan1 cells with CSFE and treating them with NT1721 for 24 to $72 \mathrm{~h}$. FACS analysis of live cells showed that relatively low concentrations of NT1721 (30 nM) significantly decreased proliferation in both Panc1 and Capan1 cells after 48 h by 19 and $48 \%$, respectively ( $p=0.0003$ for both). Treatment with $30 \mathrm{nM}$ NT1721 for $24 \mathrm{~h}$ led only in Capan1 cells to significantly reduced proliferation $(p=0.001)$, but not in Panc1 cells (Fig. 1c). We then assessed the effect of NT1721 on the cell cycle by staining NT1721-treated cells with PI after $24 \mathrm{~h}$. NT1721 significantly increased the percentage of cells in G1 phase and decreased the S phase in Capan1 cells compared to the control (Fig. 1d), which is in line with the decreased proliferation we detected in this cell line after $24 \mathrm{~h}$. The result suggests that NT1721 decreased cell cycle progression in Capan 1 cells after $24 \mathrm{~h}$. In contrast, Panc1 cells did not display a significant change in the cell cycle after $24 \mathrm{~h}$, which is not surprising given that we did not observe a change in proliferation at this early time point (Fig. 1c,d).

NT1721 downregulated GLI transcription factors and their downstream target genes

Since we have previously shown that NT1721 decreased DNMT1 and BMI1 expression in AML cells [20] we first confirmed on the protein level that NT1721 also downregulated these genes in PDAC cells (Fig. 2a). Given that both genes are targets of GLI transcription factors $[13,22]$ we investigated whether their downregulation might be (at 

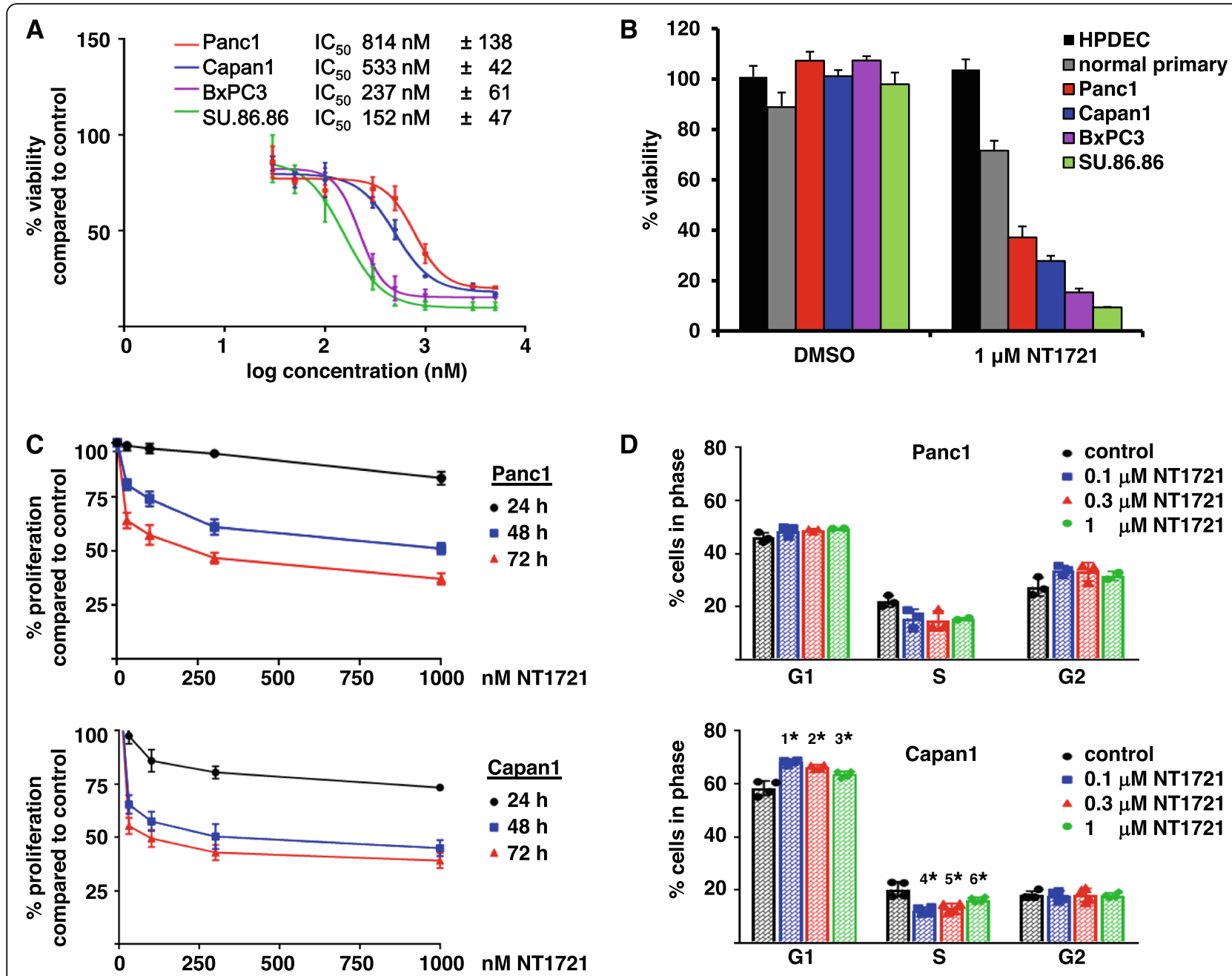

Fig. $1 \mathrm{IC}_{50}$ values of NT1721 and its effects on proliferation and cell cycle in PDAC cells. a Pancreatic cancer cell lines were treated with increasing concentrations of NT1721. The cell viability and $I_{50}$ values were determined after $48 \mathrm{~h}$. The $I_{50}$ values represent the mean \pm SD from three experiments. $\mathbf{b}$ Effect on normal pancreatic epithelial cells. PDAC cell lines, normal primary pancreatic epithelial cells and immortalized, nontumorigenic pancreatic duct epithelial cells (HPDEC) were treated with $0.3 \%$ DMSO or NT1721 and the cell viability was determined after $48 \mathrm{~h}$ using untreated cells as control. c Proliferation inhibition. PDAC cells were stained with CSFE, treated with NT1721 and subjected to FACS analysis to determine the mean fluorescence intensity after 24,48 or $72 \mathrm{~h}$. The data were normalized to the control. The values represent the mean \pm SD from three experiments. $\mathbf{d}$ Cell cycle analysis. The cells were treated with NT1721, stained with PI after $24 \mathrm{~h}$ and analyzed by FACS. The symbols $\left(1^{*}-6^{*}\right)$ indicate statistically significant differences compared to the control with $p$ values of $0.0005,0.0015,0.015,0.0022,0.0054$ and 0.0388 , respectively. The values represent the mean \pm SD from four experiments

least partially) mediated by decreased GLI signaling: RNAseq data from various cancer cell lines suggested that treatment with NT1721 led to the downregulation of GLI1 and GLI2, which we then confirmed on the mRNA (Fig. 2b) and protein level (Fig. 2a) in Panc1 and Capan1 cells. A time-course experiment revealed that NT1721 $(500 \mathrm{nM})$ significantly decreased GLI1 and GLI2 mRNA levels after $8 \mathrm{~h}$ of treatment. However, GLI2 mRNA expression was significantly reduced earlier (after $4 \mathrm{~h}$ ) and to a much greater degree in both cell lines compared to GLI1 expression (Fig. 2c), suggesting that GLI2 may be a major (direct or indirect) target of NT1721. To confirm that GLI signaling was aberrantly activated in Panc1 and
Capan1 cells we compared GLI mRNA expression levels of PDAC and non-tumorigenic HPDEC cells: GLI1 mRNA levels were overexpressed in both PDAC cell lines by 6 -20-fold. GLI2 mRNA levels were only elevated in Capan1 cells (Fig. 2d). These results confirmed the aberrant activation of the $\mathrm{HH}$ pathway in these cell lines since high GLI1 mRNA expression levels are considered to be a reliable indicator of activated $\mathrm{HH}$ signaling; high GLI2 levels are also a sign of activated $\mathrm{HH}$ signaling because GLI2 induces GLI1 transcription by binding to its promoter [23]. In contrast, upregulation of GLI2 by GLI1 is presumed to be indirect [24]. Moreover, BMI1 was also significantly overexpressed in both PDAC cell lines 


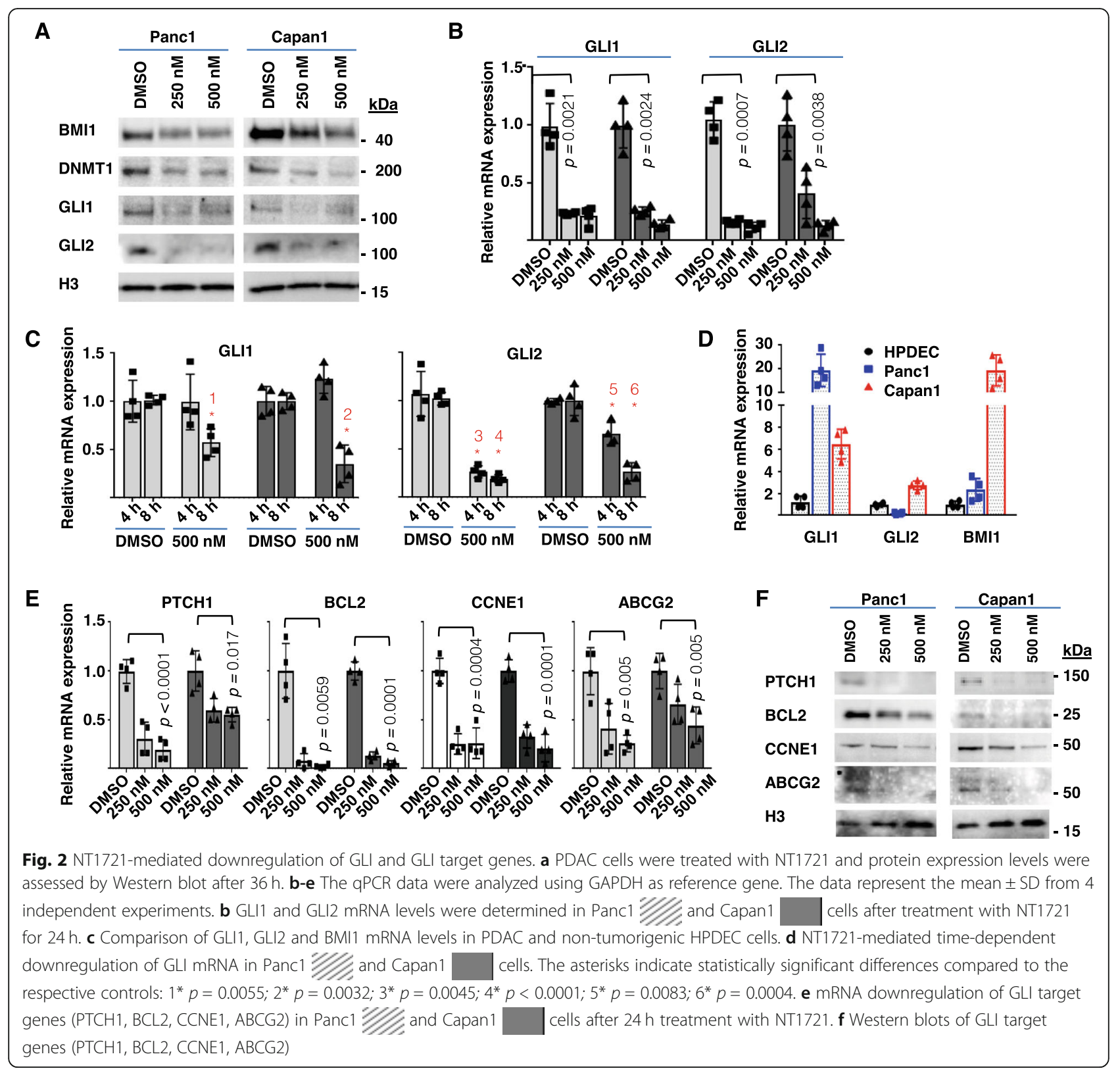

compared to HPDEC cells (Fig. 2d), which is in line with reports showing that BMI1 expression depends on $\mathrm{HH}$ pathway activity in several tumors $[16,25,26]$. To further verify that GLI-mediated signaling was attenuated after treatment with NT1721 we determined the expression levels of additional downstream targets of the GLI transcription factors: PTCH1, BCL2, CCNE1 and ABCG2 $[9,15,26,27]$. QPCR analyses revealed that these genes were also downregulated after treatment with NT1721 for 24h (Fig. 2e). Downregulation of PTCH1, BCL2, CCNE1 and ABCG2 was also confirmed on the protein level (Fig. 2f). Taken together, these results suggest that NT1721 may decrease HH/GLI signaling through downregulation of GLI transcription factors.
NT1721 displayed significantly lower $\mathrm{IC}_{50}$ values than clinically used hedgehog pathway inhibitors

To compare the efficacy of NT1721 and clinically used hedgehog inhibitors (i.e. erismodegib, vismodegib) against PDAC we treated Panc1 and Capan1 cells with the drugs or NT1721. Treatment of Panc1 cells for $48 \mathrm{~h}$ with 1 or $10 \mu \mathrm{M}$ NT1721 reduced the viability by 50 and $69 \%$, respectively, while treatment with $10 \mu \mathrm{M}$ erismodegib or vismodegib resulted only in a $7-12 \%$ reduction in viability (Fig. 3a). Our results are in line with previous reports showing that vismodegib did not significantly reduce Panc1 viability at low micromolar concentrations $(1 \mu \mathrm{M})$ [28-30]. Similar effects were observed in Capan1 cells: Treatment of 


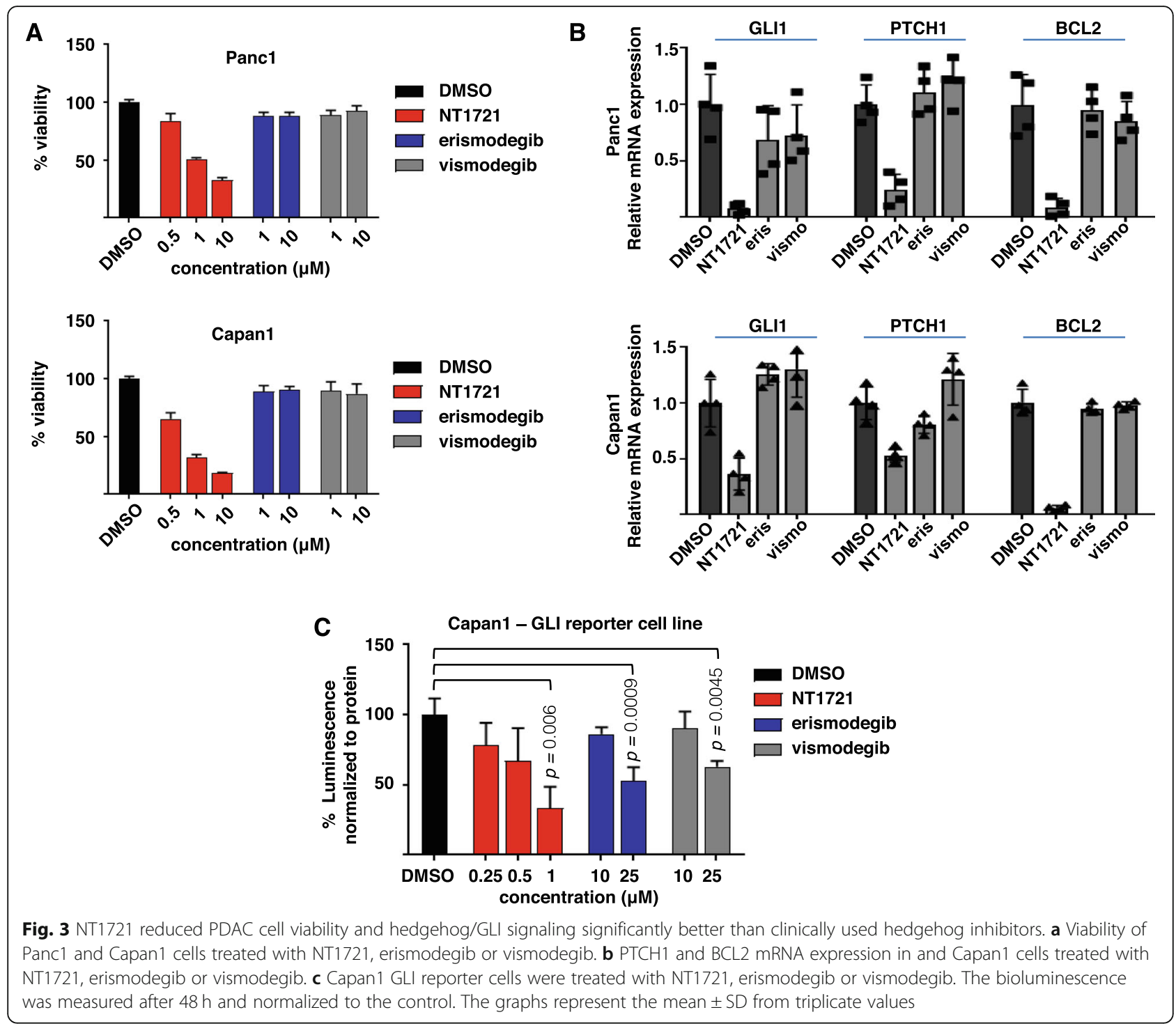

Capan1 cells with 1 or $10 \mu \mathrm{M}$ NT1721 reduced the viability by 69 and $82 \%$, respectively, while treatment with $10 \mu \mathrm{M}$ erismodegib or vismodegib reduced the viability only by $10-13 \%$. These results indicate that 10-fold lower concentrations of NT1721 led to a significantly better reduction in cell viability in both Panc1 and Capan1 cells compared to erismodegib and vismodegib. To assess the effect of the drugs on hedgehog signaling we also compared their effect on the expression of hedgehog/GLI target genes. Treating PDAC cells with $10 \mu \mathrm{M}$ erismodegib or vismodegib did not significantly reduce the GLI1, PTCH1 and BCL2 mRNA expression (Fig. 3b). In contrast, treatment of PDAC cells with $500 \mathrm{nM}$ NT1721 was sufficient to significantly decrease the expression of GLI1, PTCH1 and BCL2, demonstrating that NT1721 reduced the expression of hedgehog/GLI target genes at 20-fold lower concentrations compared to erismodegib and vismodegib. To further assess the effect of the drugs on hedgehog/GLI signaling, we established a Capan1 GLI reporter cell line using a lentiviral vector that expressed luciferase under the control of four GLI response elements. We treated the Capan1 GLI reporter cell line with the drugs and measured the luciferase activity after $36 \mathrm{~h}$. Treatment with $1 \mu \mathrm{M}$ NT1721 was sufficient to significantly reduce the luminescence while 10-fold higher concentrations of erismodegib or vismodegib did not significantly affect the luminescence (Fig. 3c). However, a significant reduction in luminescence was observed after treatment with $25 \mu \mathrm{M}$ erismodegib or vismodegib, indicating that NT1721 decreased the luminescence and thus hedgehog/GLI signaling at 25-fold lower concentrations. Taken together, our data show that NT1721 
reduced hedgehog/GLI signaling at significantly lower concentrations in both Panc1 and Capan1 cells compared to erismodegib and vismodegib.

\section{NT1721 induced the expression of tumor suppressor} genes and decreased the invasive potential of PDAC Decreased BMI1 expression has been linked to the reexpression of several tumor suppressor genes including BIM (BCL2L11), p21 (CDKN1A) [31, 32]. Thus we examined whether the NT1721-mediated reduction of BMI1 expression induced the re-expression of these tumor suppressors. As shown in Fig. 4a, NT1721 led to a strong upregulation of BIM and p21 in both cell lines.
Treatment with NT1721 was also associated with a significant, $>80 \%$ decrease in CDK2 mRNA levels in both cell lines (Fig. 4b), which was confirmed on the protein level (Fig. 4a). This is in line with previous reports showing that lower BMI1 expression levels are associated with decreased CDK2 expression and thus cell cycle progression and proliferation [32-34].

Since aberrant HH/GLI signaling is linked to increased EMT, invasion and metastasis in various cancers including PDAC $[16,17]$ we assessed the effect of NT1721-mediated GLI downregulation on the invasive potential of PDAC cells: We used the CytoSelect ${ }^{\text {tw }}$ Cell Invasion Assay (Cell Biolabs) to quantify the ability of NT1721-treated PDAC

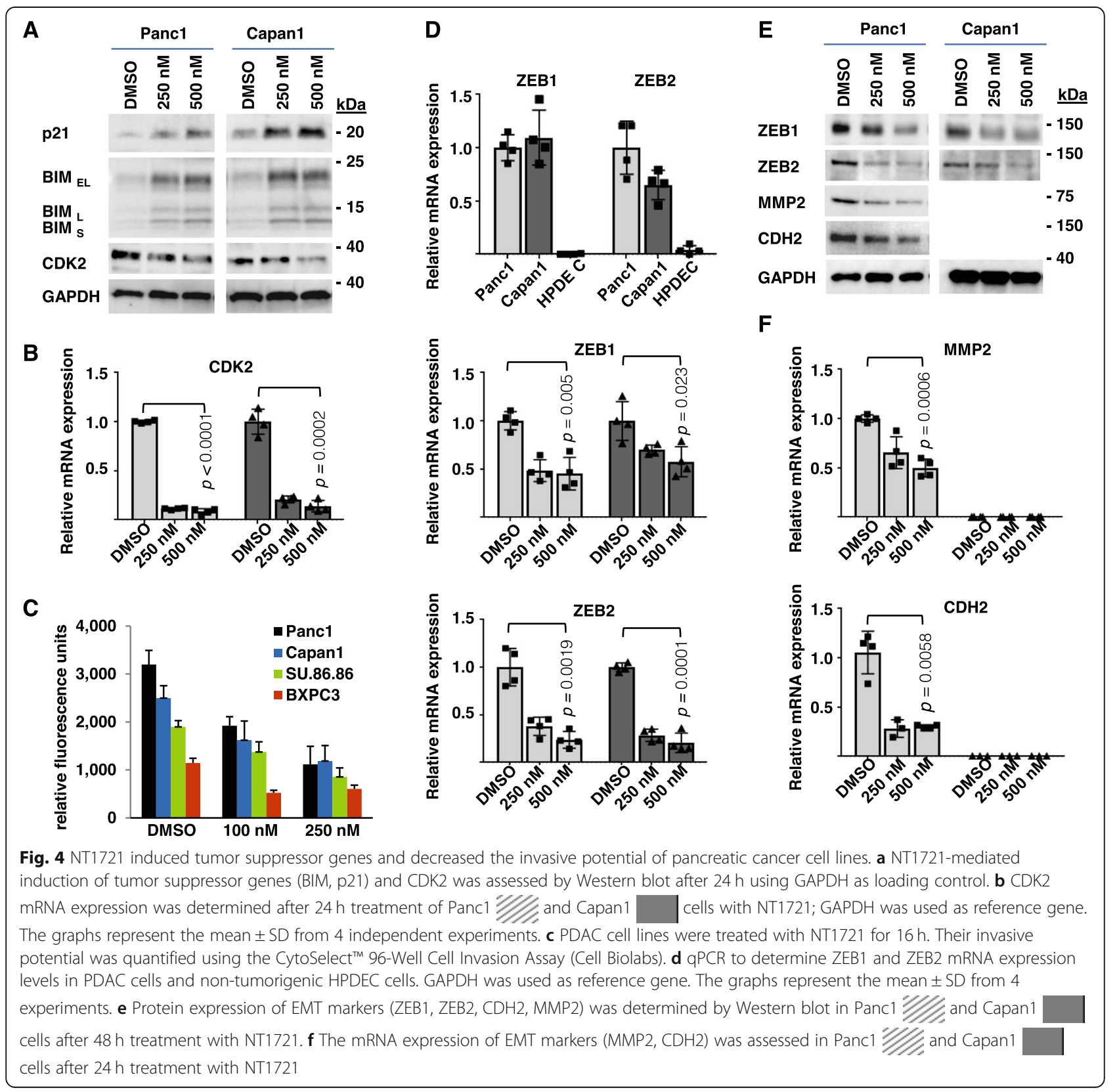


cell lines to migrate through the basement membrane. NT1721 significantly reduced the migration through the basement membrane in a concentration-dependent manner by 2-3-fold in all PDAC cell lines (Fig. 4c). To investigate the changes leading to the decreased invasion we then examined the expression of several genes associated with EMT and invasion: Previous reports show that HH/GLI signaling can indirectly induce the EMT-associated expression of ZEB1 and ZEB2 [27, 35]. Thus, we first verified that the ZEB transcription factors were upregulated in the PDAC cells by comparing the mRNA expression levels in Panc1, Capan1 and non-tumorigenic HPDEC cells: Both ZEB1 and ZEB2 were highly expressed in Panc1 and Capan1 cells compared to HPDEC (Fig. 4d), suggesting that GLI signaling may (at least partially) drive their expression. Treatment of PDAC cells with NT1721 reduced the mRNA expression of both ZEB1 and ZEB2 in Panc1 and Capan1 cells (Fig. 4d) and downregulation of ZEB1 was also confirmed on the protein level (Fig. 4e). We then also investigated whether NT1721 (similar to HH inhibitors such as GANT61, erismodegib and cyclopamine) could decrease the expression of $\mathrm{CDH} 2$ and MMP2 [36-38]. As shown in Fig. 4f, NT1721 decreased the mRNA expression of both CDH2 and MMP2 in Panc1 cells. Downregulation of $\mathrm{CDH} 2$ was also confirmed on the protein level in Panc1 cells (Fig. 4e). No CDH2 mRNA or protein expression was detected in Capan1 cells (Fig. 4e,f). Taken together, the data suggest that NT1721 reduced the invasive potential of PDAC cells through downregulation of multiple EMT markers.

\section{Antitumor effects of NT1721 depend at least partially on GLI downregulation}

To investigate the importance of GLI downregulation for the antitumor effects of NT1721 we overexpressed myctagged GLI2 $\triangle \mathrm{N}$ [21] in PDAC cells (Additional file 1: Figure S1a). We compared the effect of NT1721 treatment on the viability of GLI $2 \Delta \mathrm{N}$-overexpressing and GFP-expressing control cells. As shown in Additional file 1: Figure S1b, treatment with a low concentration of NT1721 (250 nM) failed to reduce the viability of GLI2 $\Delta \mathrm{N}$-overexpressing cells in both cell lines while significantly reducing the viability of GFP-expressing cells by $20-30 \%$. Treatment with $500 \mathrm{nM}$ NT1721 did not reduce the viability of NT1721-treated GLI2 $\Delta 2$-expressing Capan1 cells while reducing the viability of the control cells by $50 \%$. The viability of Panc1 cells treated with $500 \mathrm{nM}$ NT1721 was reduced to a lesser extend in GLI2 $\Delta 2$-expressing cells compared to the control cells. These results suggest that the effects of NT1721 may at least partially relay on GLI downregulation. To further investigate this we then determined the effects of NT1721 on GLI1, BCL2 and ZEB1 mRNA levels in GLI2 $\triangle \mathrm{N}$-overexpressing and GFP-expressing control cells: As shown in Additional file 1: Figure S1c, GLI2 $\Delta \mathrm{N}$ overexpression prevented GLI1 downregulation in both Panc1 and Capan1 cells after treatment with $250 \mathrm{nM}$ NT1721 while the GLI1 mRNA levels were reduced by $>80 \%$ in NT1721-treated, GFP-expressing control cells. This result was expected given that GLI2 induces GLI1 transcription [23]. NT1721 failed to downregulate BCL2, a direct GLI target gene, in GLI2 $\triangle \mathrm{N}$-expressing cells while NT1721 reducing BCL2 expression levels by > $70 \%$ in control cells (Additional file 1: Figure S1c). We also assessed ZEB1 expression in these cells since forced GLI2 expression has been shown to increase ZEB1 expression in pancreatic cancer cells [39]. As shown in Additional file 1: Figure S1c, ZEB1 was downregulated to a significantly lesser degree in GLI2 $\Delta \mathrm{N}$-overexpressing cells compared to GFPexpressing control cells. Taken together, these results suggest that the antitumor effects of NT1721 may at least partially depend on GLI downregulation.

\section{NT1721 reduced tumor growth, metastasis and significantly prolonged survival in orthotopic mouse models of pancreatic cancer}

To study the in vivo efficacy of NT1721 against pancreatic cancer we first treated NSG mice bearing orthotopically growing Panc1 luciferase-expressing (luc ${ }^{+}$) tumors with 30 $\mathrm{mg} / \mathrm{kg}$ of NT1721 for 3 consecutive days per week or the vehicle control (5\% DMSO / 30\% solutol in PBS) [20]. Bioluminescent imaging revealed a statistically significant $\sim 4$ fold difference between the treatment and the control groups 18 days after the treatment started $\left(p=1 \times 10^{-6}\right)$ (Fig. 5a). The mice were euthanized after 5 weeks of treatment and the weight of the primary tumor was determined. As shown in Fig. 5b, the tumor weight was significantly lower (by 54\%) in treated mice compared to the control mice $(p=0.0001)$. To investigate the effect of NT1721 on liver metastasis we harvested the livers after 5 weeks of treatment, prepared tissue slides and quantified the number of tumor foci/ $\mu^{2}$ in the liver tissue from NT1721-treatedand control mice. As shown in Fig. 5c, NT1721 significantly reduced the number of tumor foci in the liver (by 92\%) compared to control mice $(n=8, p=0.0007)$, indicating that NT1721 efficiently reduced metastasis formation in the liver. We then compared the antitumor efficacy of NT1721 and gemcitabine by treating tumor-bearing mice with NT1721 $(30 \mathrm{mg} / \mathrm{kg})$ or gemcitabine $(100 \mathrm{mg} / \mathrm{kg}$, twice per week) $(n=16)$. As shown in Fig. 5 d, we detected a significant difference in tumor growth between NT1721- and gemcitabine-treated mice: Compared with the control mice, tumor growth was reduced by $61 \%$ in the NT1721-treated mice and by $44 \%$ in the gemcitabine-treated group $(p=0.0002)$, suggesting that NT1721 may inhibit tumor growth better than gemcitabine. To assess the influence of NT1721 and gemcitabine on metastasis we treated mice bearing luc ${ }^{+}$-tumors for 5 weeks, injected D-luciferin, euthanized them and immediately compared the bioluminescent signals from the livers in the control and treatment 


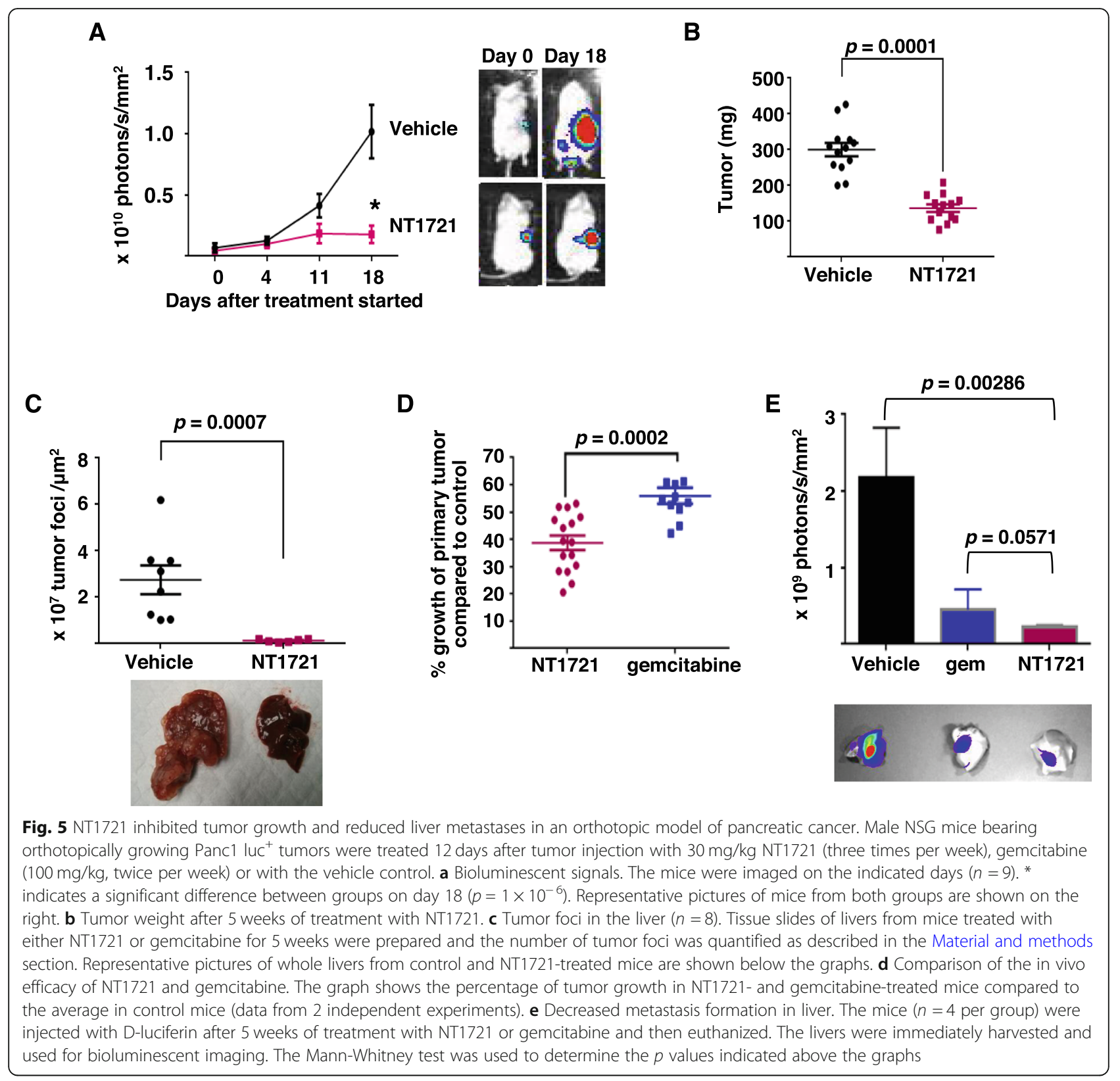

groups $(n=4)$. Livers from the NT1721-treated group displayed 8-fold lower bioluminescent signals than the control group; in contrast, livers from the gemcitabine-treated mice showed only a 5 -fold reduction in bioluminescent signals compared to the control (Fig. 5e). The difference between the control and the NT1721 group was statistically significant $(p=0.00286)$. However, the difference between the NT1721- and gemcitabine-treated groups did not reach statistical significance $(p=0.0571)$.

We then compared the efficacy of NT1721 and gemcitabine in a second mouse model: NSG mice bearing orthotopically growing Capan1 luc ${ }^{+}$tumors were treated with NT1721, gemcitabine or the vehicle control. Bioluminescent imaging showed that both NT1721 and gemcitabine reduced the tumor growth in treated mice compared to the control group in a comparable manner during the first 25 days of treatment (Fig. 6a). However, weighing the primary tumors after 5 weeks of treatment revealed that mice treated with NT1721 had smaller tumors compared to mice treated with gemcitabine. NT1721-treated mice showed an $82 \%$ reduction in tumor growth while gemcitabine decreased the tumor growth only by $66 \%$ compared to the control group. The difference in tumor weight between the NT1721- and the gemcitabine-treated group was statistically significant $(p=0.045)$ (Fig. 6b,c). To compare the influence of NT1721 and gemcitabine on tumor growth and survival times of mice bearing more advanced tumors Capan1 


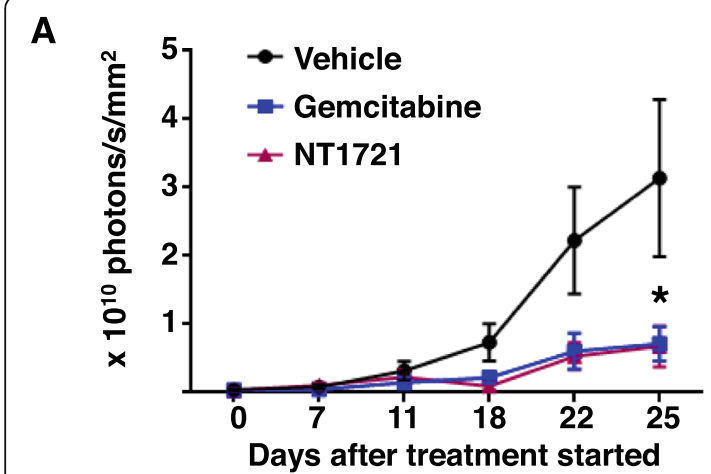

C

\section{Treatment start}

12 days after implantation

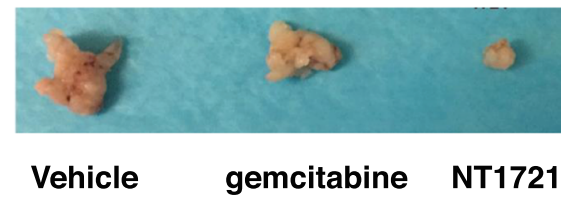

25 days after implantation

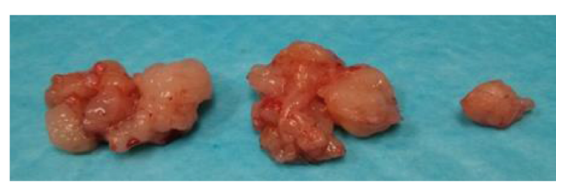

B

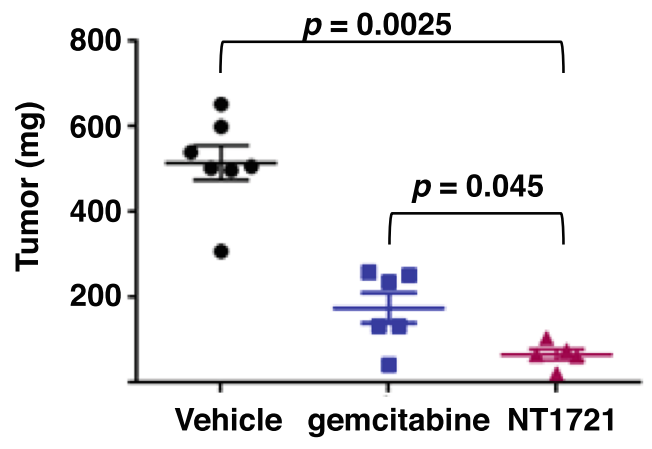

D

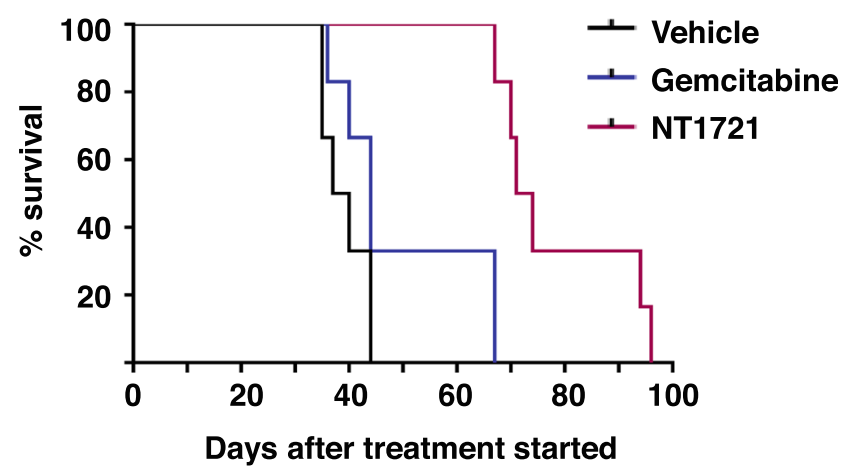

Fig. 6 NT1721 displays better antitumor efficacy than gemcitabine and prolongs survival of mice with advanced pancreatic cancer. Male NSG mice were orthotopically implanted with Capan1 luc cells. Treatment started with $30 \mathrm{mg} / \mathrm{kg}$ NT1721 (three times per week), gemcitabine (100 $\mathrm{mg} / \mathrm{kg}$, twice per week) or the vehicle control ( $n=7$ per group) 12 days (a, b) or 25 days (d) after cell implantation. a Bioluminescent signals. The mice were imaged on the indicated days. The asterisk indicates a significant difference between the control group and treatment groups (NT1721 or gemcitabine) on day $25(p<0.05)$. b Tumor weight after 5 weeks of treatment with NT1721 or gemcitabine. $P$ values were determined using Mann-Whitney test and are indicated in the graphs. c Photos of the representative primary tumors from mice that were treated with NT1721 or gemcitabine and euthanized after 5 weeks of treatment. d Survival curves. Treatment with NT1721 or gemcitabine started on day 25 after tumor implantation $(n=6)$. The log-rank test was used to determine $p$ values: The difference in survival between the control and gemcitabine treated group was significant $(p=0.029)$; the difference between the gemcitabine-treated and the NT1721-treated group was also significant $(p=0.0007)$

$\operatorname{luc}^{+}$tumors were allowed to grow orthotopically for 25 days (instead of only 12 days) before the treatment started: NT1721 clearly decreased the tumor growth of the more advanced tumors while gemcitabine did not cause an obvious decrease in tumor growth (Fig. 6c). As shown in Fig. 6d, treatment with NT1721 statistically significantly prolonged the median survival time to 71 days compared to gemcitabine-treated mice (44 days, $p=0.0007$ ) and the control group (39 days, $p=0.0007$ ). Taken together, these results show that NT1721 might be more efficacious against advanced tumors than gemcitabine.

\section{NT1721 attenuated HH/GLI signaling in vivo}

To assess the effect of NT1721 on GLI signaling in vivo we used tumor tissue from individual mice bearing Capan1 tumors for Western blot and qPCR analysis of GLI2 and GLI target genes. As shown in Fig. 7a,b, treatment with NT1721 reduced the protein expression of GLI2, PTCH1 and BMI1, statistically significantly by 72 , 83 and 78\%, respectively, recapitulating the decreases seen in PDAC cell lines in vitro. We also compared the effect of gemcitabine and NT1721 on the mRNA expression of DNMT1, a direct target gene of GLI1 [13]. DNMT1 expression was significantly reduced in NT1721-treated mice, while gemcitabine-treated mice showed DNMT1 upregulation (Fig. 7c). Taken together, our data suggest that NT1721 attenuated GLI signaling in vivo.

NT1721 also significantly reduced the mRNA expression of two genes involved in cell cycle progression, CCNE1 and CDK2, by 64 and $45 \%$, respectively, in Capan 1 tumors (Fig. 7c) and by 50 and $60 \%$, respectively, in Panc1 tumors (Fig. 7d). The results indicate that NT1721 might, at least partially, decrease the cell cycle progression and thus tumor growth through CCNE1 and CDK2 downregulation. In contrast, CCNE1 and CDK2 


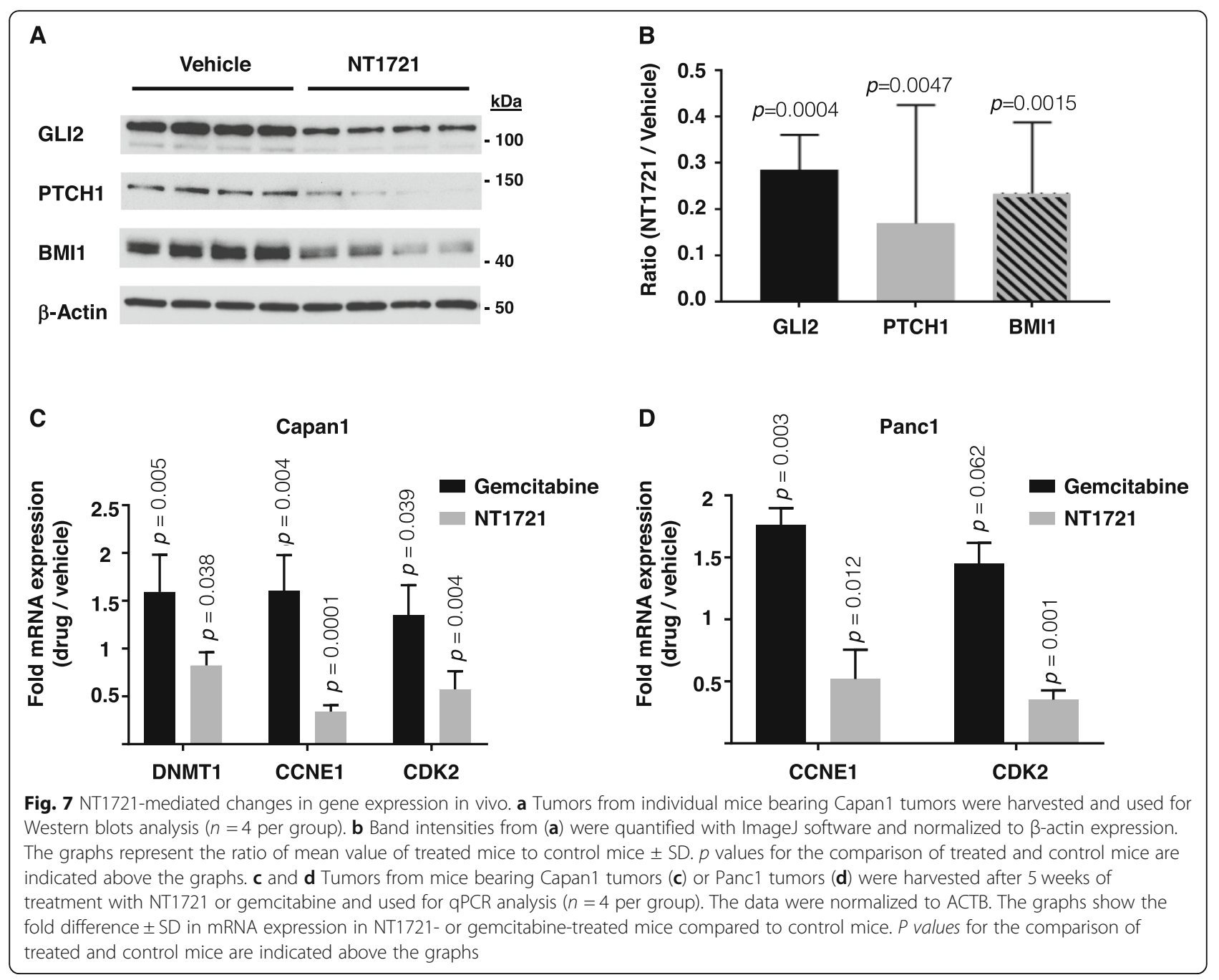

mRNA expression in gemcitabine-treated mice was significantly upregulated in both Capan 1 and Panc1 tumors compared to the control group. Since upregulated expression of CDK2, CCNE, DNMT1 is associated with accelerated cell cycle progression and thus tumor growth $[33,40]$ these results suggest that the tumors might have started to develop a drug resistance after initially responding to the treatment with gemcitabine (Fig. 6a,c).

\section{Discussion}

PDAC is still one of the deadliest cancers since $80 \%$ of patients have unresectable, metastatic disease at the time of diagnosis and more than $80 \%$ of patients undergoing surgery relapse [4]. New treatment options are desperately needed since the outcome for PDAC patients has not significantly improved over the past three decades.

Here we investigated the anti-PDAC activity of a new ETP, NT1721. The biological activity of ETPs has been linked to various molecular mechanisms [41-43]. We show for the first time that an ETP,
NT1721, can attenuate $\mathrm{HH}$ signaling through downregulation of the main mediators of $\mathrm{HH}$ signaling, GLI1 and GLI2. Treatment of PDAC cells with NT1721 decreased the expression of GLI target genes associated with EMT/ metastasis, drug resistance and the self-renewal of CSCs. These results are in line with several reports showing that $\mathrm{HH}$ inhibition can reduce CSC growth, chemoresistance and EMT in PDAC $[17,18,35,44,45]$. It is noteworthy that several of the genes (GLI1, BMI1, DNMT1, ZEB1, ZEB2) that were downregulated by NT1721 have prognostic value in PDAC since high expression levels of these genes are associated with shorter survival in PDAC patients [40, 46-48]. Reducing GLI expression has also the potential to decrease treatment failure due to an acquired drug resistance: Several studies have demonstrated that treatment with gemcitabine induced GLI expression, which led to GLI-mediated upregulation of stem cell genes such as CD24, ABCG2, BMI1 and gemcitabine resistance [7, 44, 49]. 
Resistance to a BRAF inhibitor, vemurafenib, has also been linked to GLI overexpression [36]. Moreover, PDAC cells displaying an acquired resistance to the BET bromodomain inhibitor JQ1 showed dramatically elevated GLI2 levels [50]. Treatment of these resistant cells with $\mathrm{HH}$ inhibitors or GLI knockdown restored their drug sensitivity $[7,36,44,49,50]$. Taken together these studies indicate that inhibiting the $\mathrm{HH}$ pathway could improve the prognosis for PDAC patients by potentially preventing treatment failure due to inherent or acquired upregulation of tumor stem cell and/or drug resistance genes.

$\mathrm{HH}$ inhibitors such as cyclopamine (SMO inhibitor) or GANT61 (GLI inhibitor) have shown promising results in vitro and in vivo against PDAC: Cyclopamine decreased the viability of several PDAC cell lines, reduced invasion and reversed gemcitabine resistance $[17,18,51]$. However, cyclopamine, like other SMOtargeting hedgehog inhibitors (erismodegib, vismodegib), had no effect on $\mathrm{HH}$ ligand-independent cell lines such as Panc1 at low micromolar concentrations $(<10 \mu \mathrm{M})([17,51]$, Fig. 3). A report by Yauch et al. shows that the sensitity of PDAC cell lines to SMObased $\mathrm{HH}$ inhibitors does not correlate with GLI1 or SMO mRNA expression levels at low drug concentrations; the authors concluded that the decrease in cell viability at high concentrations of SMO inhibitors may be due to off-target effects [52]. However, GANT61, which directly targets GLI downstream of SMO, inhibited the growth of $\mathrm{HH}$ ligand-independent Panc1 cells with an reported $\mathrm{IC}_{50}$ value of $5 \mu \mathrm{M}$ after $48 \mathrm{~h}$ treatment [53]. Thus, GLI inhibitors like GANT61 are advantageous in cancers where SMO contains an activating mutation or GLI activation is SHH ligandindependent and driven by e.g. KRAS mutations or by TGF $\beta$-driven GLI2 expression [12]. Since NT1721 potently $\left(\mathrm{IC}_{50}<1 \mu \mathrm{M}\right)$ inhibited the growth of $\mathrm{HH}$ ligand-independent Panc1 cells it is unlikely that NT1721 targets SMO or the HH pathway upstream of SMO. Given that GLI2 can directly induce GLI1 transcription and given that NT1721 downregulated GLI2 mRNA expression at an earlier time point and to a greater degree than GLI1 mRNA expression it seems possible that NT1721 interfered with TGF $\beta$-induced GLI2 mRNA expression. However, the exact mechanism how NT1721 mediates GLI downregulation needs to be further investigated.

\section{Conclusion}

In summary, NT1721 displayed better efficacy in controlling tumor growth and metastasis in preclinical orthotopic mouse models of PDAC than the standardof-care drug, gemcitabine. Importantly, NT1721 is orally available, well tolerated in mice and significantly prolonged survival compared to the standard-of-care drug, gemcitabine. Thus, our data provide a rational for testing NT1721 in the clinic either as a single agent or potentially in combination with gemcitabine or other therapeutic agents in PDAC patients overexpressing GLI transcription factors.

\section{Supplementary information}

Supplementary information accompanies this paper at https://doi.org/10. 1186/s13046-019-1445-z

Additional file 1: Figure S1. Antitumor effects of NT1721 depend at least partially on GLI downregulation. a Overexpression of myc-tagged, activated GLI2 (GLI2 $\Delta 2)$ in Panc1 and Capan1 cells. b Viability of GLI2 $\Delta N$ overexpressing and GFP-expressing control cells after treatment with 250 nM NT1721. The symbols $\left(1^{*}-3^{*}\right)$ indicate statistically significant differences compared to the control with $p$ values of $0.003,0.01$ and $<0.001$, respectively. c Expression levels of GLI1, BCL2 and ZEB1 in GLI2 $\triangle N$ overexpressing and GFP-expressing control cells after treatment with 250 nM NT1721. The graphs represent the mean \pm SD from triplicate values.

\section{Abbreviations}

CSCs: Cancer stem cells; CSFE: 5(6)-Carboxyfluorescein N-

hydroxysuccinimidylester; EMT: Epithelial-to-mesenchymal transition; ETP: Epidithiodiketopiperazine; HH: Hedgehog; HPDEC: Human pancreatic ductal epithelial cells; MFI: Median fluorescence intensity; PDAC: Pancreatic ductal epithelial carcinoma

\section{Acknowledgements}

The work was supported by the A. Gary Anderson Family Foundation (to D.A.H), the Panda Charitable Foundation (to D.A.H), and NIH grant R01GM098601 (to L.E.O). Research reported in this publication included work performed in the Drug Discovery and Structural Biology, Analytical Flow Cytometry, Pathology, and Light Microscopy Cores that are supported by the National Cancer Institute of the National Institutes of Health Cancer Center Support Grant (P30CA33572).

\section{Authors' contributions}

Conception, writing, revision: CMK, LEO, DAH; Acquisition, analysis and interpretation of data: CMK, ML, JX. All authors read and approved the final manuscript.

\section{Funding}

The work was supported by the A. Gary Anderson Family Foundation (to D.A.H), the Panda Charitable Foundation (to D.A.H), and NIH grant R01GM098601 (to L.E.O).

\section{Availability of data and materials}

All data generated or analyzed during this study are included within the article.

\section{Ethics approval and consent to participate}

The experimental protocol for animal studies was reviewed and approved by the institutional animal care and use committee of City of Hope National Medical Center.

\section{Consent for publication}

Not applicable.

\section{Competing interests}

D.A.H and L.E.O are co-founders of Novonco Therapeutics Inc. A patent related to this work was filed by City of Hope.

\section{Author details}

${ }^{1}$ Department of Molecular Medicine, City of Hope National Medical Center, 1500 E. Duarte Road, Duarte, CA 91010, USA. ²Department of Chemistry, 1102 Natural Sciences II, University of California, Irvine, CA 92697-2025, USA. 


\section{Received: 5 June 2019 Accepted: 10 October 2019} Published online: 28 October 2019

\section{References}

1. Siegel RL, Miller KD, Jemal A. Cancer statistics, 2019. CA Cancer J Clin. 2019; 69(1):7-34 PubMed PMID: 30620402.

2. Polireddy K, Chen Q. Cancer of the pancreas: molecular pathways and current advancement in treatment. J Cancer. 2016;7(11):1497-514 PubMed PMID: 27471566. Pubmed Central PMCID: 4964134

3. Han H, Von Hoff DD. SnapShot: pancreatic cancer. Cancer Cell. 2013;23(3): 424-424.e1 PubMed PMID: 23518352. Pubmed Central PMCID: 3638898.

4. Garrido-Laguna I, Hidalgo M. Pancreatic cancer: from state-of-the-art treatments to promising novel therapies. Nat Rev Clin Oncol. 2015;12(6): 319-34 PubMed PMID: 25824606

5. Conroy T, Desseigne F, Ychou M, Bouche O, Guimbaud R, Becouarn Y, et al. FOLFIRINOX versus gemcitabine for metastatic pancreatic cancer. N Engl J Med. 2011;364(19):1817-25 PubMed PMID: 21561347.

6. Hermann PC, Huber SL, Herrler T, Aicher A, Ellwart JW, Guba M, et al. Distinct populations of cancer stem cells determine tumor growth and metastatic activity in human pancreatic cancer. Cell Stem Cell. 2007;1(3): 313-23 PubMed PMID: 18371365

7. Quint K, Tonigold M, Di Fazio P, Montalbano R, Lingelbach S, Ruckert F, et al. Pancreatic cancer cells surviving gemcitabine treatment express markers of stem cell differentiation and epithelial-mesenchymal transition. Int J Oncol. 2012;41(6):2093-102 PubMed PMID: 23026911.

8. Rimkus TK, Carpenter RL, Qasem S, Chan M, Lo HW. Targeting the sonic hedgehog signaling pathway: review of smoothened and GLI inhibitors. Cancers. 2016:8(2). https://doi.org/10.3390/cancers8020022 PubMed PMID: 26891329. Pubmed Central PMCID: 4773745

9. Berman DM, Karhadkar SS, Maitra A, Montes De Oca R, Gerstenblith MR, Briggs $\mathrm{K}$, et al. Widespread requirement for hedgehog ligand stimulation in growth of digestive tract tumours. Nature. 2003;425(6960):846-51 PubMed PMID: 14520411

10. Ramaswamy B, Lu Y, Teng KY, Nuovo G, Li X, Shapiro CL, et al. Hedgehog signaling is a novel therapeutic target in tamoxifen-resistant breast cancer aberrantly activated by PI3K/AKT pathway. Cancer Res. 2012;72(19):5048-59 PubMed PMID: 22875023. Pubmed Central PMCID: 3837449

11. Rajurkar M, De Jesus-Monge WE, Driscoll DR, Appleman VA, Huang H, Cotton $J$, et al. The activity of Gli transcription factors is essential for Krasinduced pancreatic tumorigenesis. Proc Natl Acad Sci U S A. 2012;109(17): E1038-47 PubMed PMID: 22493246. Pubmed Central PMCID: 3340052

12. Javelaud D, Alexaki VI, Dennler S, Mohammad KS, Guise TA, Mauviel A. TGF-beta/SMAD/GLI2 signaling axis in cancer progression and metastasis. Cancer Res. 2011;71(17):5606-10 PubMed PMID: 21862631. Pubmed Central PMCID: 3165102

13. He S, Wang F, Yang L, Guo C, Wan R, Ke A, et al. Expression of DNMT1 and DNMT3a are regulated by GLI1 in human pancreatic cancer. PLoS One. 2011;6(11):e27684 PubMed PMID: 22110720. Pubmed Central PMCID: 3215738 .

14. Eichberger T, Sander V, Schnidar H, Regl G, Kasper M, Schmid C, et al. Overlapping and distinct transcriptional regulator properties of the GLI1 and GLI2 oncogenes. Genomics. 2006;87(5):616-32 PubMed PMID: 16434164

15. Singh RR, Kunkalla K, Qu C, Schlette E, Neelapu SS, Samaniego F, et al. ABCG2 is a direct transcriptional target of hedgehog signaling and involved in stroma-induced drug tolerance in diffuse large B-cell lymphoma. Oncogene. 2011:30(49):4874-86 PubMed PMID: 21625222. Pubmed Central PMCID: 3165099

16. Liu S, Dontu G, Mantle ID, Patel S, Ahn NS, Jackson KW, et al. Hedgehog signaling and Bmi-1 regulate self-renewal of normal and malignant human mammary stem cells. Cancer Res. 2006;66(12):6063-71 PubMed PMID: 16778178. Pubmed Central PMCID: 4386278.

17. Feldmann G, Dhara S, Fendrich V, Bedja D, Beaty R, Mullendore M, et al. Blockade of hedgehog signaling inhibits pancreatic cancer invasion and metastases: a new paradigm for combination therapy in solid cancers. Cancer Res. 2007;67(5):2187-96 PubMed PMID: 17332349. Pubmed Central PMCID: 3073370

18. Yao J, An Y, Wie JS, Ji ZL, Lu ZP, Wu JL, et al. Cyclopamine reverts acquired chemoresistance and down-regulates cancer stem cell markers in pancreatic cancer cell lines. Swiss Med Wkly. 2011;141:w13208 PubMed PMID: 21630164
19. Baumann M, Dieskau AP, Loertscher BM, Walton MC, Nam S, Xie J, et al. Tricyclic analogues of epidithiodioxopiperazine alkaloids with promising and antitumor activity. Chem Sci. 2015;6:4451-7 PubMed PMID: 26301062. Pubmed Central PMCID: 4540405.

20. Kowolik CM, Lin M, Xie J, Overman LE, Horne DA. NT1721, a novel epidithiodiketopiperazine, exhibits potent in vitro and in vivo efficacy against acute myeloid leukemia. Oncotarget. 2016;7(52):86186-97 PubMed PMID: 27863389

21. Roessler E, Ermilov AN, Grange DK, Wang A, Grachtchouk M, Dlugosz AA, et al. A previously unidentified amino-terminal domain regulates transcriptional activity of wild-type and disease-associated human GLI2. Hum Mol Genet. 2005;14(15):2181-8 PubMed PMID: 15994174.

22. Wang $X$, Venugopal C, Manoranjan B, McFarlane N, O'Farrell E, Nolte S, et al. Sonic hedgehog regulates Bmi1 in human medulloblastoma brain tumor-initiating cells. Oncogene. 2012;31(2):187-99 PubMed PMID: 21685941.

23. Ikram MS, Neill GW, Regl G, Eichberger T, Frischauf AM, Aberger F, et al. GLI2 is expressed in normal human epidermis and BCC and induces GLI1 expression by binding to its promoter. J Invest Dermatol. 2004;122(6):1503-9 PubMed PMID: 15175043.

24. Regl G, Neill GW, Eichberger T, Kasper M, Ikram MS, Koller J, et al. Human GLI2 and GLI1 are part of a positive feedback mechanism in basal cell carcinoma. Oncogene. 2002;21(36):5529-39 PubMed PMID: 12165851.

25. Beachy PA, Karhadkar SS, Berman DM. Tissue repair and stem cell renewal in carcinogenesis. Nature. 2004;432(7015):324-31 PubMed PMID: 15549094.

26. Regl G, Kasper M, Schnidar H, Eichberger T, Neill GW, Philpott MP, et al. Activation of the BCL2 promoter in response to hedgehog/GLI signal transduction is predominantly mediated by GLI2. Cancer Res. 2004;64(21): 7724-31 PubMed PMID: 15520176.

27. Katoh $Y$, Katoh M. Hedgehog target genes: mechanisms of carcinogenesis induced by aberrant hedgehog signaling activation. Curr Mol Med. 2009; 9(7):873-86 PubMed PMID: 19860666

28. Singh BN, Fu J, Srivastava RK, Shankar S. Hedgehog signaling antagonist GDC-0449 (Vismodegib) inhibits pancreatic cancer stem cell characteristics: molecular mechanisms. PLoS One. 2011;6(11):e27306 PubMed PMID: 22087285. Pubmed Central PMCID: 3210776.

29. Kumar V, Chaudhary AK, Dong Y, Zhong HA, Mondal G, Lin F, et al. Design, synthesis and biological evaluation of novel hedgehog inhibitors for treating pancreatic cancer. Sci Rep. 2017;7(1):1665 PubMed PMID: 28490735. Pubmed Central PMCID: 5431907

30. Zhou Q, Zhou Y, Liu X, Shen Y. GDC-0449 improves the antitumor activity of nano-doxorubicin in pancreatic cancer in a fibroblast-enriched microenvironment. Sci Rep. 2017;7(1):13379 PubMed PMID: 29042665. Pubmed Central PMCID: 5645386

31. Jacobs JJ, Kieboom K, Marino S, DePinho RA, van Lohuizen M. The oncogene and Polycomb-group gene bmi-1 regulates cell proliferation and senescence through the ink4a locus. Nature. 1999;397(6715):164-8 PubMed PMID: 9923679.

32. Xu Z, Liu H, Lv X, Liu Y, Li S, Li H. Knockdown of the Bmi-1 oncogene inhibits cell proliferation and induces cell apoptosis and is involved in the decrease of Akt phosphorylation in the human breast carcinoma cell line MCF-7. Oncol Rep. 2011:25(2):409-18 PubMed PMID: 21152871.

33. Balasubramanian S, Adhikary G, Eckert RL. The Bmi-1 polycomb protein antagonizes the (-)-epigallocatechin-3-gallate-dependent suppression of skin cancer cell survival. Carcinogenesis. 2010;31(3):496-503 PubMed PMID: 20015867. Pubmed Central PMCID: 2832547.

34. Lee K, Adhikary G, Balasubramanian S, Gopalakrishnan R, McCormick T, Dimr $\mathrm{GP}$, et al. Expression of Bmi-1 in epidermis enhances cell survival by altering cell cycle regulatory protein expression and inhibiting apoptosis. J Invest Dermatol. 2008;128(1):9-17 PubMed PMID: 17625597. Pubmed Central PMCID: 3043461.

35. Fu J, Rodova M, Roy SK, Sharma J, Singh KP, Srivastava RK, et al. GANT-61 inhibits pancreatic cancer stem cell growth in vitro and in NOD/SCID/IL2R gamma null mice xenograft. Cancer Lett. 2013;330(1):22-32 PubMed PMID: 23200667. Pubmed Central PMCID: 4153855.

36. Faiao-Flores F, Alves-Fernandes DK, Pennacchi PC, Sandri S, Vicente AL, Scapulatempo-Neto $C$, et al. Targeting the hedgehog transcription factors GLI1 and GLI2 restores sensitivity to vemurafenib-resistant human melanoma cells. Oncogene. 2017;36(13):1849-61 PubMed PMID: 27748762 Pubmed Central PMCID: 5378933.

37. Nanta R, Kumar D, Meeker D, Rodova M, Van Veldhuizen PJ, Shankar S, et al. NVP-LDE-225 (Erismodegib) inhibits epithelial-mesenchymal transition and 
human prostate cancer stem cell growth in NOD/SCID IL2Rgamma null mice by regulating Bmi-1 and microRNA-128. Oncogenesis. 2013;2:e42 PubMed PMID: 23567619. Pubmed Central PMCID: 3641359.

38. Che J, Zhang FZ, Zhao CQ, Hu XD, Fan SJ. Cyclopamine is a novel hedgehog signaling inhibitor with significant anti-proliferative, anti-invasive and anti-estrogenic potency in human breast cancer cells. Oncol Lett. 2013; 5(4):1417-21 PubMed PMID: 23599805. Pubmed Central PMCID: 3629107.

39. Adams CR, Htwe HH, Marsh T, Wang AL, Montoya ML, Subbaraj L, et al. Transcriptional control of subtype switching ensures adaptation and growth of pancreatic cancer. Elife. 2019;8. https://doi.org/10.7554/eLife.45313 PubMed PMID: 31134896. Pubmed Central PMCID: 6538376

40. Gao J, Wang L, Xu J, Zheng J, Man X, Wu H, et al. Aberrant DNA methyltransferase expression in pancreatic ductal adenocarcinoma development and progression. J Exp Clin Cancer Res. 2013;32:86 PubMed PMID: 24423239. Pubmed Central PMCID: 4029463

41. Cook KM, Hilton ST, Mecinovic J, Motherwell WB, Figg WD, Schofield CJ. Epidithiodiketopiperazines block the interaction between hypoxia-inducible factor-1alpha (HIF-1alpha) and p300 by a zinc ejection mechanism. J Biol Chem. 2009;284(39):26831-8 PubMed PMID: 19589782. Pubmed Central PMCID: 2785371.

42. Lakshmikuttyamma A, Scott SA, DeCoteau JF, Geyer CR. Reexpression of epigenetically silenced AML tumor suppressor genes by SUV39H1 inhibition Oncogene. 2010;29(4):576-88 PubMed PMID: 19881540

43. Li J, Zhang Y, Da Silva Sil Dos Santos B, Wang F, Ma Y, Perez C, et al. Epidithiodiketopiperazines inhibit protein degradation by targeting proteasome Deubiquitinase Rpn11. Cell Chem Biol. 2018;25(11):1350-8.e9 PubMed PMID: 30146242

44. Huang FT, Zhuan-Sun YX, Zhuang YY, Wei SL, Tang J, Chen WB, et al, Inhibition of hedgehog signaling depresses self-renewal of pancreatic cancer stem cells and reverses chemoresistance. Int J Oncol. 2012;41(5): 1707-14 PubMed PMID: 22923052.

45. Bao C, Kramata P, Lee HJ, Suh N. Regulation of hedgehog signaling in cancer by natural and dietary compounds. Mol Nutr Food Res. 2018;62(1). https://doi.org/10.1002/mnfr.201700621 PubMed PMID: 29164817.

46. Marechal R, Bachet JB, Calomme A, Demetter P, Delpero JR, Svrcek M, et al. Sonic hedgehog and Gli1 expression predict outcome in resected pancreatic adenocarcinoma. Clin Cancer Res. 2015;21(5):1215-24 PubMed PMID: 25552484

47. Kurahara H, Takao S, Maemura K, Mataki Y, Kuwahata T, Maeda K, et al. Epithelial-mesenchymal transition and mesenchymal-epithelial transition via regulation of ZEB-1 and ZEB-2 expression in pancreatic cancer. J Surg Oncol. 2012;105(7):655-61 PubMed PMID: 22213144.

48. Song W, Tao K, Li H, Jin C, Song Z, Li J, et al. Bmi-1 is related to proliferation, survival and poor prognosis in pancreatic cancer. Cancer Sci. 2010;101(7):1754-60 PubMed PMID: 20426791.

49. Yin T, Wei H, Leng Z, Yang Z, Gou S, Wu H, et al. Bmi-1 promotes the chemoresistance, invasion and tumorigenesis of pancreatic cancer cells. Chemotherapy. 2011;57(6):488-96 PubMed PMID: 22248802

50. Kumar K, Raza SS, Knab LM, Chow CR, Kwok B, Bentrem DJ, et al. GLI2-dependent C-MYC upregulation mediates resistance of pancreatic cancer cells to the BET bromodomain inhibitor JQ1. Sci Rep. 2015;5:9489 PubMed PMID: 25807524 Pubmed Central PMCID: 4452877.

51. Steg A, Amm HM, Novak Z, Frost AR, Johnson MR. Gli3 mediates cell survival and sensitivity to cyclopamine in pancreatic cancer. Cancer Biol Ther. 2010;10(9):893-902 PubMed PMID: 20814245. Pubmed Central PMCID: 3230294.

52. Yauch RL, Gould SE, Scales SJ, Tang T, Tian H, Ahn CP, et al. A paracrine requirement for hedgehog signalling in cancer. Nature. 2008; 455(7211):406-10 PubMed PMID: 18754008.

53. Lauth M, Bergstrom A, Shimokawa T, Toftgard R. Inhibition of GLI-mediated transcription and tumor cell growth by small-molecule antagonists. Proc Natl Acad Sci U S A. 2007;104(20):8455-60 PubMed PMID: 17494766. Pubmed Central PMCID: 1866313

\section{Publisher's Note}

Springer Nature remains neutral with regard to jurisdictional claims in published maps and institutional affiliations.

\section{Ready to submit your research? Choose BMC and benefit from}

- fast, convenient online submission

- thorough peer review by experienced researchers in your field

- rapid publication on acceptance

- support for research data, including large and complex data types

- gold Open Access which fosters wider collaboration and increased citations

- maximum visibility for your research: over $100 \mathrm{M}$ website views per year

At BMC, research is always in progress.

Learn more biomedcentral.com/submissions 